\title{
Erratum to: Workplace Outcomes in Work-Disability Prevention Research: A Review with Recommendations for Future Research
}

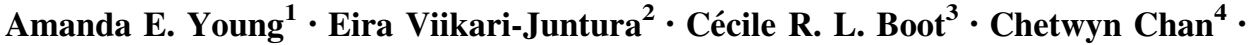 \\ David Gimeno Ruiz de Porras ${ }^{5} \cdot$ Steven J. Linton ${ }^{6}$ The Hopkinton Conference Working \\ Group on Workplace Disability Prevention
}

Published online: 24 November 2016

(c) Springer Science+Business Media New York 2016

Erratum to: J Occup Rehabil (2016) 26:434-447
DOI 10.1007/s10926-016-9675-9

In the published version, the fifth author, David Gimeno Ruiz de Porras, has been incorrectly cited as de Porras DG. His surname is Gimeno Ruiz de Porras and his first name is David. The correct citation with initial for first name is Gimeno Ruiz de Porras D.

This has been corrected with this erratum.

The online version of the original article can be found under doi:10.1007/s10926-016-9675-9.

Amanda E. Young

Amandae.young@libertymutual.com

1 Liberty Mutual Research Institute for Safety, 71 Frankland

Road, Hopkinton, MA 01748, USA

2 Finnish Institute of Occupational Health, Helsinki, Finland

3 EMGO Institute, VU University Medical Center, Amsterdam, The Netherlands

4 The Hong Kong Polytechnic Institute, Hong Kong, China

5 The University of Texas Health Science Center at Houston, Houston, TX, USA

6 Center for Health and Medical Psychology, Örebro University, Örebro, Sweden 